\title{
Can less be more in orthodontic diagnosis?
}

\section{I Masoud*}

Director of Orthodontics, Department of Developmental Biology, Harvard School of Dental Medicine, Boston, USA

The quote "less is more" from Robert Browning's 1855 Poem in the voice of the renaissance artist Andrea del Sarto has inspired many and was adopted as a way of life by architects and visionaries like Mies van der Rohe and Buckminster Fuller [1-3].

In this inaugural issue of an exciting new journal called Dental, Oral and Craniofacial Research (DOCR), I thought it would be fitting to reflect on how the concept of "less is more" can relate to the future of orthodontic diagnosis.

Nostradamus predicted that in 2015 the average human life span will be 200 years, advances in the science of telepathy will enable people to communicate with animals, and that this would be the year we resurrect the dead [4]. Although it seems that we have not quite kept up with Nostradamus's prophecies, the practice of orthodontics is undergoing some major changes. Many offices no longer use braces, robots now make it possible for an orthodontist to practice without knowing how to bend wire, patients come in asking for magical brackets that can grow bone and move teeth faster, orthodontist tell patients to bite on vibrating devices to accelerate tooth movement, and drilling titanium screws into alveolar bone has become part of everyday orthodontic practice.

Orthodontic diagnosis and planning is one of those peculiar areas where major technological advances have not necessarily advanced traditional concepts. Orthodontic treatment mainly influences the lower third of the face but we still expose the entire cranium when taking a lateral skull cephalogram just to use part of it as a reference for our measurements. We continue to 1 measure dental and facial discrepancies relative to the cranial base which has been shown to be inaccurate [5-7]. Despite all radiation exposure guidelines recommending against routine radiographic exposure of any kind [812 ], some orthodontists are advocating routinely taking cone beam computer tomographs (CBCT) on all orthodontic patients, including children, only to convert them into two dimensional cephalometric radiographs to perform traditional measurements developed over half a century ago [13-17]. Systematic reviews have concluded that there is no high quality evidence to support the use of CBCT in orthodontics $[18,19]$ and cephalometric radiographs have been shown not to contribute significantly to treatment planning decisions [20-22]. Despite the radiation we routinely expose our patients to, we frequently plan the position of the teeth based on an unrelated view of the dental arches orientated with the occlusal plane parallel to the floor.

A systematic review in 2013 concluded that the minimum record set required for orthodontic diagnosis and treatment planning could not be defined [23]. We therefore have a long way to go and it may be time to pause and question some of our practices. Are we talking radiographs because we need them for diagnostic information to provide the best possible care, or are we taking them to complete our specialty board requirements? Why are we exposing the whole cranium?
Is there an alternative reference area that can be used to measure dental and facial relationships without radiographic exposure? Do we always need to see the roots of teeth to decide on the correct orientation of the crowns? Shouldn't we diagnose and treatment plan cases looking at the teeth in the correct orientation relative to the face instead of a construct with the occlusal plane parallel to the floor?

In an attempt to answer some of these questions we have been working on developing and testing an alternative to traditional cephalometric diagnosis that involves indexing three dimensional photographic images of the face and teeth and measuring dental and facial discrepancies relative to the eyes and natural head position. This could potentially result in making an orthodontic diagnosis with no radiation above what is required for regular dental care. To create an appropriate reference group that the public considers attractive, we have orthodontically screened the teeth of over 350 face models and conducted layperson surveys for attractiveness for the prescreened group of models. Refining and testing the evaluation process is currently being conducted on an orthodontic population.

We anticipate this technique to be promising since previous research has shown that hard and soft tissue measurements correlate well with each other [24,25], the position and size of the eyes are relatively stable in the age group that receive orthodontic treatment $[26,27]$, and natural head position is reliable and reproducible $[6,7]$. However, as with all new techniques we still need to demonstrate the usefulness of this technique in making orthodontic decisions.

Likewise, advocates of the routine use of CBCT imaging need to provide evidence to support its necessity for routine orthodontic diagnosis and treatment planning before it should be considered the standard of care.

"Any intelligent fool can make things bigger and more complex... It takes a touch of genius --- and a lot of courage to move in the opposite direction."

Hopefully, this quote by EF Schumacher's (which is often attributed to Einstein) holds true, and less is actually more in orthodontic diagnosis.

Perhaps in the future the ideal set of orthodontic records will include a limited field cone beam image of the teeth and alveolar

Correspondence to: M I Masoud, Director of Orthodontics, Department of Developmental Biology, Harvard School of Dental Medicine, 188 Longwood Ave, Boston MA 02115, Tel: 617432 4281; Fax: 6174323246, E-mail: mohamed_masoud@hsdm.harvard.edu; masoudortho@gmail.com

Received: January 10, 2015; Accepted: January 17, 2015; Published: January 25 2015 
process indexed to a three dimensional photograph of the face and the teeth.

Only future well designed and conducted research will support the premise that less is more when obtaining orthodontic diagnostic records.

\section{References}

1. Robert Browning. Men and Women,Transcendentalism: A Poem In Twelve Books, EPN Press, 2009 ISBN 1-934255-21-1.

2. Aalden Whitman. "Mies van der Rohe Dies at 83; Leader of Modern Architecture". The New York Times. August 17, 1969.

3. Brand, Stewart (1999). The Clock of the Long Now. New York: Basic. ISBN 0-46504512-X.

4. Nostradamus, M. Les Propheties, Lyon: Bonhomme. 1555.

5. Jacobson A (1975) The "Wits" appraisal of jaw disharmony. Am J Orthod 67: 125-138. [Crossref]

6. Moorrees CF, uan Venrooij ME, Lebret LM, Glatky CG, Kent RL, et al. (1976) New norms for the mesh diagram analysis. Am J Orthod 69: 57-71. [Crossref]

7. Lundström A, Lundström F, Lebret LM, Moorrees CF (1995) Natural head position and natural head orientation: basic considerations in cephalometric analysis and research. Eur J Orthod 17: 111-120. [Crossref]

8. Turpin DL (2008) British Orthodontic Society revises guidelines for clinical radiography. Am J Orthod Dentofacial Orthop 134: 597-598. [Crossref]

9. Isaacson KG, Thom AR, Horner K, Whaites E. Orthodonticradiographs-guidelines for the use of radiographs in clinical orthodontics. 3rd ed. London: British Orthodontic Society; 2008

10. Remedios D, McCoubrie P, The Royal College Of Radiologists Guidelines Working Party (2007) Making the best use of clinical radiology services: a new approach to referral guidelines. Clin Radiol 62: 919-920. [Crossref]

11. Ruf S. TMD and the daily orthodontic practice. World J Orthod 2005; 6(Suppl):210

12. Atchison KA, Luke LS, White SC (1992) An algorithm for ordering pretreatment orthodontic radiographs. Am J Orthod Dentofacial Orthop 102: 29-44. [Crossref]

13. Smith BR, Park JH, Cederberg RA (2011) An evaluation of cone-beam computed tomography use in postgraduate orthodontic programs in the United States and Canada. $J$ Dent Educ 75: 98-106. [Crossref]

14. Larson BE (2012) Cone-beam computed tomography is the imaging technique of choice for comprehensive orthodontic assessment. Am J Orthod Dentofacial Orthop 141: 402, 404, 406 passim. [Crossref]
15. Pauwels R, Beinsberger J, Collaert B, Theodorakou C, Rogers J, et al. (2012) Effective dose range for dental cone beam computed tomography scanners. Eur J Radiol 81 : 267-271. [Crossref]

16. Kuijpers-Jagtman AM, Kuijpers MA, Schols GH, Maal TJ, Breuning KH, et al. (2013) The use of cone-beam computed tomography for Orthodontic purposes. Semin Orthod 19:196-203

17. Halazonetis DJ (2012) Cone-beam computed tomography is not the imaging technique of choice for comprehensive orthodontic assessment. Am J Orthod Dentofacial Orthop 141: 403, 405, 407 passim. [Crossref]

18. van Vlijmen OJ, Kuijpers MA, Bergé SJ, Schols JG, Maal TJ, et al. (2012) Evidence supporting the use of cone-beam computed tomography in orthodontics. $J$ Am Dent Assoc 143: 241-252. [Crossref]

19. Pittayapat P, Limchaichana-Bolstad N, Willems G, Jacobs R (2013) Three-dimensiona cephalometric analysis in orthodontics: a systematic review. Orthod Craniofac Res.

20. Nijkamp PG, Habets LL, Aartman IH, Zentner A (2008) The influence of cephalometrics on orthodontic treatment planning. Eur J Orthod 30: 630-635. [Crossref]

21. Devereux L, Moles D, Cunningham SJ, McKnight M (2011) How important are latera cephalometric radiographs in orthodontic treatment planning? Am J Orthod Dentofacial Orthop 139: e175-181. [Crossref]

22. Kim JC, Mascarenhas AK, Joo BH, Vig KW, Beck FM, et al. (2000) Cephalometric variables as predictors of Class II treatment outcome. Am J Orthod Dentofacial Orthop 118: 636-640. [Crossref]

23. Rischen RJ, Breuning KH, Bronkhorst EM, Kuijpers-Jagtman AM (2013) Records needed for orthodontic diagnosis and treatment planning: a systematic review. PLoS One 8: e74186. [Crossref]

24. Kochel J, Meyer-Marcotty P, Strnad F, Kochel M, Stellzig-Eisenhauer A (2010) 3D soft tissue analysis--part 1: sagittal parameters. J Orofac Orthop 71: 40-52. [Crossref]

25. Kochel J, Meyer-Marcotty P, Kochel M, Schneck S, Stellzig-Eisenhauer A (2010) 3D soft tissue analysis--part 2: vertical parameters. J Orofac Orthop 71: 207-220. [Crossref]

26. Dijkstal JM, Bothun ED, Harrison AR, Lee MS (2012) Normal exophthalmometry measurements in a United States pediatric population. Ophthal Plast Reconstr Surg 28: 54-56. [Crossref]

27. MacLachlan C, Howland HC (2002) Normal values and standard deviations for pupi diameter and interpupillary distance in subjects aged 1 month to 19 years. Ophthalmic Physiol Opt 22: 175-182. [Crossref]

28. Schumacher EF; Small is beautiful: Economics as if people mattered. New York: Harper and Row, 1973.

Copyright: (C2015 Masoud MI. This is an open-access article distributed under the terms of the Creative Commons Attribution License, which permits unrestricted use, distribution, and reproduction in any medium, provided the original author and source are credited. 